\title{
Comparison of three risk scores to predict outcomes in upper gastrointestinal bleeding; modifying Glasgow-Blatchford with albumin
}

\author{
AFSHIN SHAFAGHI $\dagger^{1}$, FAEZE GHARIBPOOR $\dagger^{2}$, ZAHRA MAHDIPOUR $\dagger^{2}$, ALI AKBAR SAMADANI \\ ${ }^{1}$ Gastrointestinal and Liver Diseases Research Center, Guilan University of Medical science, Rasht, Iran \\ ${ }^{2}$ Student Research Committee, Faculty of Medicine, Guilan University of Medical Sciences, Rasht, Iran \\ $\dagger$ These authors contributed equally to this work.
}

\begin{abstract}
Introduction. Management of upper gastrointestinal bleeding (UGIB) is of great importance. In this way, we aimed to evaluate the performance of three well known scoring systems of AIMS65, Glasgow-Blatchford Score (GBS) and Full Rockall Score (FRS) in predicting adverse outcomes in patients with UGIB as well as their ability in identifying low risk patients for outpatient management. We also aimed to assess whether changing albumin cutoff in AIMS65 and addition of albumin to GBS add predictive value to these scores.

Methods. This was a retrospective study on adult patients who were admitted to Razi hospital (Rasht, Iran) with diagnosis of upper gastrointestinal bleeding between March 21, 2013 and March 21, 2017. Patients who didn't undergo endoscopy or had incomplete medical data were excluded. Initially, we calculated three score systems of AIMS65, GBS and FRS for each patient by using initial Vital signs and lab data. Secondary, we modified AIMS65 and GBS by changing albumin threshold from $<3.5$ to $<3.0$ in AIMS65 and addition of albumin to GBS, respectively. Primary outcomes were defined as in hospital mortality, 30-day rebleeding, need for blood transfusion and endoscopic therapy. Secondary outcome was defined as composition of primary outcomes excluding need for blood transfusion. We used AUROC to assess predictive accuracy of risk scores in primary and secondary outcomes. For albumin-GBS model, the AUROC was only calculated for predicting mortality and secondary outcome. The negative predictive value for AIMS65, GBS and modified AIMS65 was then calculated.

Result. Of 563 patients, 3\% died in hospital, $69.4 \%$ needed blood transfusion, $13.1 \%$ needed endoscopic therapy and 3\% had 30-day rebleeding. The leading cause of UGIB was erosive disease. In predicting composite of adverse outcomes all scores had statistically significant accuracy with highest AUROC for albumin-GBS. However, in predicting in hospital mortality, only albumin-GBS, modified AIMS65 and AIMS65 had acceptable accuracy. Interestingly, albumin, alone, had higher predictive accuracy than other original risk scores. None of the four scores could predict 30-day rebleeding accurately; on the contrary, their accuracy in predicting need for blood transfusion was high enough. The negative predictive value for GBS was $96.6 \%$ in score of $\leq 2$ and $85.7 \%$ and $90.2 \%$ in score of zero in AIMS65 and modified AIMS65, respectively.

Conclusion. Neither of risk scores was highly accurate as a prognostic factor in our population; however, modified AIMS65 and albumin-GBS may be optimal choice in evaluating risk of mortality and general assessment. In identifying patient for safe discharge, GBS $\leq 2$ seemed to be advisable choice.
\end{abstract}

Key words: upper gastrointestinal bleeding, scoring systems, risk assessment, Glasgow-Blatchford, Rockall, AIMS65, albumin.

\section{INTRODUCTION}

Upper gastrointestinal bleeding (UGIB) is considered as one of the most common emergency condition with more than 300,000 hospital admissions per year in the United States and mortality rates between $2 \%$ and $15 \%$ [1]. Despite the advances in the management and endoscopic therapy strategies, rate of mortality has not significantly improved [2].

Correspondingly, recent studies have found some risk factors independently predicting adverse outcomes. These risk factors include: history of peptic ulcer [3], increase in BUN [4], hemodynamic instability, lower serum sodium, hemoglobin and platelet count $[5,6]$, combination of tumor and NSAIDs, liver cirrhosis and coagulopathy [7, 8], higher serum bilirubin, creatinine [9], lactate $[10,11]$ and lower serum albumin [12].

Conspicuously, the presence of numerous risk factors as well as the fact that patients with UGIB are often initially managed by junior doctors, necessitate the development of validated risk scoring 
systems [2]. Therefore, multiple systems have been designed and recommended by international guidelines [13]. The most well-known systems are Rockall Score, Glasgow-Blatchford Score and recently developed system called AIMS65 [14]. Each of these systems was first designed to predict specific outcome. GBS was primarily developed to predict requirement for clinical intervention; while Rockall and AIMS65 were designed to predict mortality $[1,15,16]$.

Following the introduction of these systems, numerous studies have been conducted to validate them [2] and the discrepancy in results led to the idea that variation in geographical region and health care system affects the accuracy of risk scores [17-19]. Although, many guidelines suggest that low risk patients can be managed as outpatient, In our hospital all patients with UGIB undergo endoscopy and the timing is mostly within the first 24 hours of admission [14, 20]. In this study our primary object was to compare AIMS65, GlasgowBlatchford Score (GBS) and Full Rockall Score (FRS) to find out whether they have acceptable accuracy in our hospital and to find the best pre endoscopy score for identifying low risk patients.

Relatively, modifying these scoring systems by adding risk factors that independently predict adverse outcomes, have been investigated in several studies $[10,11]$. As mentioned earlier, hypoalbuminemia is considered to be a risk factor for more adverse outcome [12]; However an optimal cut off for maximizing the predictive ability of albumin seems to be different in studies [21-23]. In this way, our second objective was to investigate whether changing albumin threshold from $<3$ to $<3.5$ can increase the accuracy of AIMS65 or not.

Moreover, since GBS is the preferred scoring system in predicting the need for clinical intervention [20, 24-26], our third objective was to assess whether addition of albumin to this system can increase its predictive accuracy in predicting mortality or not.

\section{MATERIAL AND METHODS}

\section{Data collection}

This was a retrospective study on patients who were admitted to Razi teaching hospital (Rasht, Iran) with diagnosis of UGIB between March 21, 2013 and March 21, 2017. Diagnosis of gastrointestinal bleeding was made on presentation of hematemesis and melena confirmed by upper endoscopy. Patients were either admitted to emergency ward or referred to gastrointestinal ward from other hospitals or other wards of Razi hospital. Exclusion criteria were as follows: (1) age under 18; (2) patients who didn't undergo endoscopy; (3) didn't have sufficient lab data for at least one scoring system. Data required for three scoring systems of AIMS65, GBS and FRS were collected and are as follows: age, sex, altered mental state, systolic blood pressure, pulse rate, INR, albumin, hemoglobin, BUN, presence of syncope, melena and comorbidity, inpatient mortality, length of hospitalization, need for blood transfusion, endoscopic therapy and findings of first endoscopy. For patients who were admitted more than one time we obtained data of first admission of the study period. The study protocol was confirmed by the ethic institute of student research committee, Faculty of Medicine, Guilan University of Medical Science.

\section{Measurement and outcomes}

We calculated AIMS65, GBS and FRS for each patient. Criteria's of each scoring system are summarized in Table 1. We divided patients to high and low risk groups according to the cut off point that maximized the sum of sensitivity and specificity in inpatient mortality. As the next step, we compared primary outcomes and mean of hospital length of stay within high risk and low risk groups. Primary Outcomes were defined as follows: (1) inpatient mortality, related or nonrelated to UGIB; (2) rebleeding defined as any hemorrhage in gastrointestinal system occurred during 30 days after admission; (3) need for receiving blood transfusion; (4) endoscopic therapy defined as any intervention to stop bleeding or prevent rebleeding. Secondary outcome was defined as Composite of adverse outcomes excluding need for blood transfusion.

As the next step, we changed albumin threshold for AIMS65 from $<3$ to $<3.5$ and named it "modified AIMS65" to see whether its negative predictive value in identifying low risk patients and its accuracy in predicting inpatient mortality and adverse outcome is higher than original AIMS65 or not. The negative predictive value was then calculated for GBS in score of 0,1, 2 and for AIMS65 and modified AIMS65 in score of 0 . 
Table 1

AIMS65 Score, Glasgow-Blatchford Score, Full Rockall Score

\begin{tabular}{|c|c|c|c|c|}
\hline \multicolumn{5}{|c|}{ AIMS65 } \\
\hline Risk factor & \multicolumn{4}{|c|}{ Score } \\
\hline Albumin $<3.0 \mathrm{~g} / \mathrm{DL}$ & \multicolumn{4}{|c|}{1} \\
\hline INR $>1.5$ & \multicolumn{4}{|c|}{1} \\
\hline Altered mental status & \multicolumn{4}{|c|}{1} \\
\hline $\mathrm{SBP}<90 \mathrm{~mm} \mathrm{Hg}$ & \multicolumn{4}{|c|}{1} \\
\hline Age $>65$ years & \multicolumn{4}{|c|}{1} \\
\hline \multicolumn{5}{|c|}{ Glasgow-Blatchford Score } \\
\hline \multirow[t]{2}{*}{ Risk facto } & \multicolumn{4}{|c|}{$\begin{array}{ll}\text { Score } \\
\end{array}$} \\
\hline & 1 & 2 & 3 & 5 \\
\hline \multicolumn{2}{|l|}{ Blood urea nitrogen, mg/DL } & $\geq 18.2$ to $<22.4$ & $\geq 22.4$ to $<28$ & $\geq 28$ to $<70$ \\
\hline Hemoglobin, men, g/DI & $\geq 12$ to $<13$ & & $\geq 10$ to $<12$ & $<10$ \\
\hline Hemoglobin, women, g/Dl & $\geq 10$ to $<12$ & & & $<10$ \\
\hline SBP, mm Hg & $100-109$ & $90-99$ & $<90$ & \\
\hline Other markers & \multicolumn{3}{|c|}{$\begin{array}{ll}\text { Heart rate } \geq 100 \mathrm{bpm}, & \text { Syncope, Hepatic disease, } \\
\text { Melena } & \text { Heart failure }\end{array}$} & \\
\hline \multicolumn{5}{|c|}{$\begin{array}{l}\text { Full Rockall Score } \\
\end{array}$} \\
\hline \multirow[t]{2}{*}{ Risk factor } & \multicolumn{4}{|c|}{ Score } \\
\hline & $\mathbf{0}$ & 1 & 2 & 3 \\
\hline Age, year & $<60$ & $60-70$ & $\geq 80$ & \\
\hline Shock & $\begin{array}{l}\text { No shock: } \mathrm{SBP} \geq 100 \text {, } \\
\text { Pulse }<100\end{array}$ & $\begin{array}{l}\text { Tachycardia:SBP } \geq 100, \\
\text { Pulse } \geq 100\end{array}$ & $\begin{array}{l}\text { Hypotension } \\
: \text { SBP }<100\end{array}$ & \\
\hline Comorbidity & $\begin{array}{l}\text { No major } \\
\text { comorbidity }\end{array}$ & & $\begin{array}{l}\text { Cardiac failure, } \\
\text { IHD, any major } \\
\text { comorbidity }\end{array}$ & $\begin{array}{l}\text { Renal failure, Liver failure, } \\
\text { Disseminated malignancy }\end{array}$ \\
\hline Diagnosis & $\begin{array}{l}\text { Mallory-Weiss tear, } \\
\text { No lesion identified } \\
\text { and No SRH }\end{array}$ & All other diagnoses & $\begin{array}{l}\text { Malignancy of } \\
\text { upper GI tract }\end{array}$ & \\
\hline Major SRH & $\begin{array}{l}\text { None or dark spot } \\
\text { only }\end{array}$ & & $\begin{array}{l}\text { Blood in upper GI } \\
\text { tract, adherent } \\
\text { clot, visible or } \\
\text { spurting vessel }\end{array}$ & \\
\hline
\end{tabular}

Using the area under the receiver-operating characteristic curve (AUROC), the accuracy of AIMS65, GBS, FRS and modified AIMS65 in predicting inpatient mortality, rebleeding, need for blood transfusion, endoscopic therapy and composite of adverse outcomes was then calculated.

Further, we evaluated the accuracy of albumin in predicting inpatient mortality independently and developed a combined model of albumin and GBS and assessed its accuracy in predicting mortality and composite of adverse outcomes.

\section{Statistical analysis}

All data were analyzed using IBM SPSS, Version 24.0. (Armonk, NY: IBM Corp.). CHI Square test was used to compare primary outcomes within high risk and low risk group for AIMS65, GBS and FRS. For comparing mean of hospital length of stay among high risk and low risk group, the T-test was used. AUROC was used to calculate predictive accuracy of each score and albumin in inpatient mortality, rebleeding, need for blood transfusion and endoscopic therapy. Binary regression analysis was used to develop the combined model of albumin-GBS. Negative predictive value was calculated using the standard formula. The MannWhitney $U$ test was used for analysis of nonparametrical data.

\section{RESULTS}

\section{Patient characteristic}

Of 810 patients who underwent endoscopy and diagnosed with UGIB, 563 patients offered sufficient data and were included in the study. The mean age was $60.53 \pm 18.62$ (range of 18 to 94). $61.3 \%$ of patients were male. The leading cause of UGIB was erosive disease (38.4\%) (Table 2). Patient characteristics are shown in Table 3. 
Table 2

Endoscopic findings

\begin{tabular}{|lc|}
\hline \multicolumn{2}{|c|}{ Etiology of upper GI bleeding } \\
\hline Erosive disease & $216[38.4]$ \\
Peptic ulcer & $211[37.5]$ \\
Malignancy of upper GI & $39[6.9]$ \\
Varices & $19[3.4]$ \\
No lesion identified & $71[12.6]$ \\
Other & $7[1.2]$ \\
\hline
\end{tabular}

Data are presented as number [\%].

Table 3

Patient characteristics

\begin{tabular}{|c|c|}
\hline Characteristic & Value \\
\hline Age, year & $60.53 \pm 18.62$ \\
\hline \multicolumn{2}{|l|}{ Sex } \\
\hline Male & $345[61.3]$ \\
\hline Female & $218[38.7]$ \\
\hline \multicolumn{2}{|l|}{ Comorbidity } \\
\hline Disseminated malignancy & $15[2.6]$ \\
\hline Malignancy of upper GI & $11[1.9]$ \\
\hline Liver failure & $15[2.6]$ \\
\hline Renal failure & $18[3.1]$ \\
\hline Heart failure & $29[5.1]$ \\
\hline Other cardiac disease[e.g. Ischemic heart disease] & $91[16.1]$ \\
\hline Other renal disease & $9[1.5]$ \\
\hline Other & $13[2.3]$ \\
\hline \multicolumn{2}{|l|}{ Laboratory variables } \\
\hline 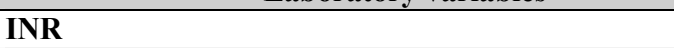 & $1.28 \pm 1.05$ \\
\hline Albumin & $3.54 \pm 0.61$ \\
\hline BUN & $33.38 \pm 26.04$ \\
\hline Hemoglobin & $8.92 \pm 2.84$ \\
\hline \multicolumn{2}{|l|}{ Clinical variables } \\
\hline Systolic blood pressure & $114.43 \pm 21.44$ \\
\hline Pulse Rate & $84.50 \pm 27.53$ \\
\hline Altered mental status & $21[3.7]$ \\
\hline Melena & $408[72.4]$ \\
\hline Syncope & $4[0.7]$ \\
\hline \multicolumn{2}{|l|}{ Outcome } \\
\hline Inpatient mortality & $17[3]$ \\
\hline 30-day Rebleeding & $17[3]$ \\
\hline Hospital length of stay, day & $5.99 \pm 3.96$ \\
\hline Blood transfusion requirement & $391[69.4]$ \\
\hline Endoscopic intervention & $74[13.1]$ \\
\hline Time to endoscopy, day & $1.47 \pm 1.93$ \\
\hline
\end{tabular}

Data are presented as mean \pm SD or number [\%].

\section{Inpatient mortality}

The overall inpatient mortality was $3 \%$. In predicting inpatient mortality, albumin-GBS, modified AIMS65 and AIMS65 had enough accuracy with AUROC of $0.75,0.72$ and 0.67 , respectively $(p<0.05)$. GBS and FRS acted poorly with AUROC of $0.58(p>0.05)$ (Figure 1). The cutoff point that maximized the sum of sensitivity and specificity was 2 for AIMS65 (sensitivity, 47.1; specificity, 79.5), 8 for GBS (sensitivity, 76.5; specificity, 39.7) and 6 for FRS (sensitivity, 29.4; specificity, 91). Comparing inpatient mortality in high risk and low risk group within AIMS65, GBS and FRS, high risk group had higher mortality rate; however, this difference wasn't significant in GBS. (AIMS65 : $(6.66 \%$ vs $2.03 \%, \mathrm{p}=0.008)$, FRS : (9.25\% vs $2.35 \%, \mathrm{p}=0.005)$, GBS : $(3.8 \%$ vs $1.8 \%$, $\mathrm{p}=0.178)$ ) (Table 4). No patient had inpatient mortality in GBS $\leq 2$ and FRS $=0$; while mortality rate was $1.29 \%$ and $0.5 \%$ in score of 0 in AIMS65 and modified AIMS65, respectively. 


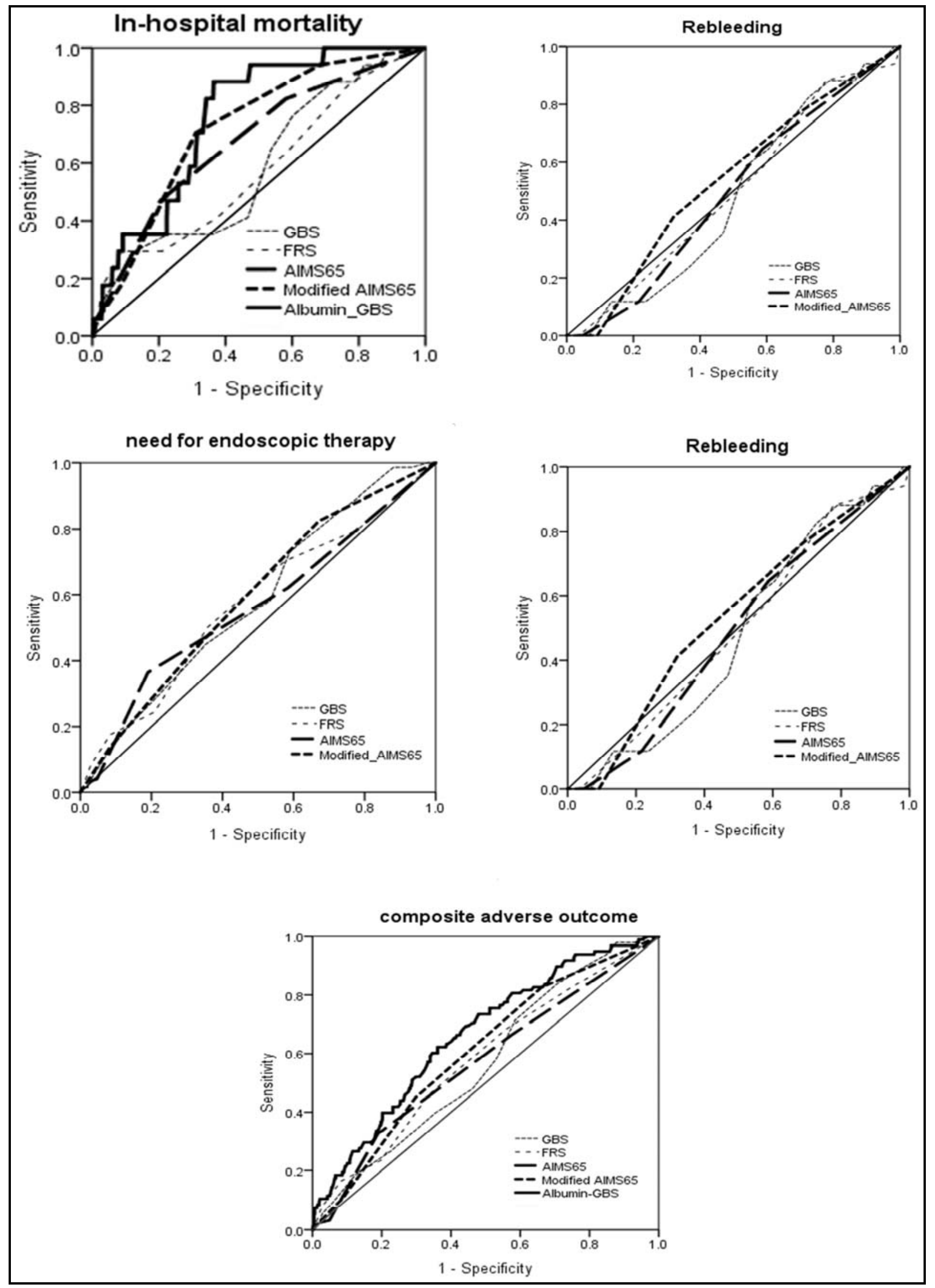

Figure 1. Reciever-operating characteristic curves (AUROCs) for the AIMS65, GBS, FRS, Modified AIMS65 and albumin-GBS in predicting in-hospital mortality, need for transfusion, endoscopic therapy, 30-day rebleeding and Composite of adverse outcome.

For albumin-GBS, the AUROC is only calculated for predicting in-hospital mortality and composite of adverse outcome. 
Table 4

Comparison of outcomes within high risk and low risk group

\begin{tabular}{|c|c|c|c|}
\hline & High risk [\%] & Low risk[\%] & P value \\
\hline \multicolumn{4}{|c|}{ Inpatient mortality } \\
\hline AIMS65 & 6.6 & 2.03 & 0.008 \\
\hline GBS & 3.8 & 1.8 & 0.178 \\
\hline FRS & 9.25 & 2.35 & 0.005 \\
\hline \multicolumn{4}{|c|}{ Blood transfusion requirement } \\
\hline AIMS65 & 90.00 & 63.88 & 0.0001 \\
\hline GBS & 77.77 & 56.56 & 0.0001 \\
\hline FRS & 87.03 & 67.58 & 0.003 \\
\hline \multicolumn{4}{|c|}{ Endoscopic intervention } \\
\hline AIMS65 & 22.5 & 10.6 & 0.001 \\
\hline GBS & 15.78 & 9.04 & 0.021 \\
\hline FRS & 24.07 & 11.98 & 0.012 \\
\hline \multicolumn{4}{|c|}{ 30-day rebleeding } \\
\hline AIMS65 & 0.35 & 3.38 & 0.329 \\
\hline GBS & 3.21 & 2.71 & 0.734 \\
\hline FRS & 1.85 & 3.14 & 0.598 \\
\hline \multicolumn{4}{|c|}{ Mean of length of hospital stay, day } \\
\hline AIMS65 & $6.87 \pm 3.94$ & $5.75 \pm 3.94$ & 0.006 \\
\hline GBS & $6.30 \pm 3.99$ & $5.51 \pm 3.87$ & 0.02 \\
\hline FRS & $5.88 \pm 3.88$ & $7.04 \pm 4.56$ & 0.04 \\
\hline
\end{tabular}

Cut off point that maximized the sum of sensitivity and specificity in inpatient mortality is used to classify patients in to high risk and low risk group. Patients are considered to be in low risk group for each score if they fall below the cut off point or in the high risk group.

\section{Serum albumin as a predictor for mortality}

Using albumin as an independent risk factor, the AUROC for predicting mortality was 0.74 . Addition albumin to GBS increased its predictive accuracy from 0.58 to 0.75 (Figure 1). Patient with inpatient mortality had lower mean of albumin comparing to survival group (3.0 Vs $3.5 \mathrm{P}<0.0001) .41 .17 \%$ of non-survival group had albumin ranging between 3 to 3.5 . Of this, $85.71 \%$ of patients were considered as low risk group according to AIMS65. Changing albumin threshold from 3 to 3.5 in AIMS65 increased its predictive accuracy from 0.67 to 0.72 .

\section{Predicting rebleeding, need for blood transfusion or for endoscopic therapy}

Remarkably, $69.4 \%$ of patients needed blood transfusion. All scores had significant predictive accuracy for predicting need for blood transfusion with AUROC of 0.70 for modified AIMS65, 0.67 for AIMS65 and GBS and 0.65 for FRS. $(\mathrm{P}<0.0001)$. For predicting need for endoscopic therapy modified AIMS65, GBS and FRS had enough accuracy with AUROC of $0.59,0.58$ and 0.58 , respectively; but AIMS65 didn't have statistically significant accuracy (AUROC $=0.56 \mathrm{p}>0.05$ ). In predicting rebleeding, modified AIMS65, FRS, AIMS65 and GBS had predictive accuracy of $0.53,0.51,0.49$, and 0.48 , respectively. Neither of them was statistically significant (Table 5).

\section{Composite of adverse outcomes}

Correspondingly, $17.4 \%$ of patients suffered from at least one component of adverse outcomes including mortality, rebleeding and need for endoscopic therapy. Using AUROC to predict composite of adverse outcome, albumin-GBS, modified AIMS65, AIMS65, FRS and GBS had predictive accuracy of $0.66,0.60,0.57,0.57,0.56$, respectively (Table 5). The negative predictive value for GBS in score of 0 was $100 \%$ and up to $96.6 \%$ in score $\leq 2$. AIMS65 and modified AIMS65 had negative predictive value of $85.7 \%$ and $90.2 \%$, respectively.

\section{Hospital length of stay}

Mean of hospital length of stay was higher in high risk group comparing to low risk group in AIMS65 $(6.87 \pm 3.94$ Vs $5.75 \pm 3.94, \mathrm{P}=0.006)$, Glasgow Blatchford $(6.30 \pm 3.99$ Vs $5.51 \pm 3.87$ $\mathrm{p}=0.02)$ and Full Rockall (5.88 \pm 3.88 Vs $7.04 \pm 4.56$, $\mathrm{P}=0.04)$. 
Table 5

Accuracy of scoring systems for predicting outcomes

\begin{tabular}{|c|c|c|}
\hline \multicolumn{3}{|c|}{ AUROC [95\% CI] p-value } \\
\hline & Inpatient mortality & \\
\hline AIMS65 & $0.675[0.545-0.806]$ & 0.014 \\
\hline GBS & $0.588[0.454-0.721]$ & 0.217 \\
\hline FRS & $0.588[0.446-0.730]$ & 0.215 \\
\hline Modified AIMS65 & $0.722[0.614-0.830]$ & 0.002 \\
\hline Albumin-GBS & $0.758[0.670-0.846]$ & $<0.0001$ \\
\hline \multicolumn{3}{|c|}{ Blood transfusion requirement } \\
\hline AIMS65 & $0.674[0.628-0.721]$ & $<0.0001$ \\
\hline GBS & $0.671[0.622-0.721]$ & $<0.0001$ \\
\hline FRS & $0.654[0.605-0.704]$ & $<0.0001$ \\
\hline Modified AIMS65 & $0.707[0.662-0.752]$ & $<0.0001$ \\
\hline \multicolumn{3}{|c|}{ Endoscopic intervention } \\
\hline AIMS65 & $0.562[0.487-0.637]$ & 0.087 \\
\hline GBS & $0.582[0.516-0.647]$ & 0.023 \\
\hline FRS & $0.586[0.515-0.657]$ & 0.017 \\
\hline Modified AIMS65 & $0.594[0.527-0.661]$ & 0.009 \\
\hline \multicolumn{3}{|c|}{ 30-day rebleeding } \\
\hline AIMS65 & $0.491[0.369-0.614]$ & 0.904 \\
\hline GBS & $0.481[0.366-0.596]$ & 0.791 \\
\hline FRS & $0.513[0.387-0.638]$ & 0.858 \\
\hline Modified AIMS65 & $0.538[0.410-0.667]$ & 0.589 \\
\hline \multicolumn{3}{|c|}{ Composite of adverse outcome } \\
\hline AIMS65 & $0.571[0.507-0.634]$ & 0.028 \\
\hline GBS & $0.565[0.507-0.624]$ & 0.041 \\
\hline FRS & $0.579[0.517-0.641]$ & 0.014 \\
\hline Modified AIMS65 & $0.604[0.545-0.663]$ & 0.001 \\
\hline Albumin-GBS & $0.661[0.604-0.718]$ & $<0.0001$ \\
\hline
\end{tabular}

GBS, Glasgow-Blatchford Score; FRS, Full Rockall Score. Pvalue of $<0.05$ indicates statistical significance of the tests.

\section{Missing values}

247 out of 810 patients didn't have sufficient lab data or other values required for calculation of the risk scores and were ruled out. Values were missing for AIMS65 score $(\mathrm{n}=228)$, GBS $(\mathrm{n}=88)$ and FRS $(\mathrm{n}=19)$, albumin $(\mathrm{n}=191)$, INR $(\mathrm{n}=95)$, BUN $(n=62)$, hemoglobin $(n=59)$, pulse rate $(n=16)$, systolic blood pressure $(n=14)$, report of endoscopy $(n=8)$, need for endoscopic therapy $(\mathrm{n}=7)$, length of hospital stay $(\mathrm{n}=2)$, transfusion $(\mathrm{n}=1)$ and mental status $(\mathrm{n}=1) .18$ patients had inpatient mortality $(7.3 \%), 19$ patients had 30 day rebleeding (7.7\%), 169 patients needed blood transfusion (68.4\%) and 34 patients needed endoscopic therapy (13.8\%). Etiology of upper GI bleeding, comorbidities and mean of laboratory values are summarized in Table 6.

\section{DISCUSSION}

Several studies have been conducted to assess accuracy of risk scoring systems in predicting outcomes of UGIB; however the results have been widely variant [2]. In this study, comparing the original scores, AIMS65 performed better than GBS and FRS in predicting inpatient mortality. This finding is consistent with other studies and introduces AIMS65 as a simple and applicable tool for predicting inpatient mortality [27-29]. However, these scores' accuracy wasn't high enough. In this way, we modified AIMS65 and GBS with albumin and interestingly, the combined model of albumin-GBS and modified AIMS65 predicted mortality better than their original version.

In our study, in predicting need for blood transfusion, all scores performed well, but modified AIMS65 had slightly better accuracy; however, in predicting need for endoscopic intervention, only modified AIMS65, GBS and FRS had meaningful accuracy $(p<0.05)$. Although, outperformance of GBS in assessment of need for clinical intervention has been shown in other studies [20, 24-26], we found modified AIMS65 as a good fit alternative.

Studies have used risk scores in predicting rebleeding and it has been shown that Patients with high Rockall score are in greater risk of rebleeding $[30,31]$, but in our study no risk scores could accurately predict 30 -day rebleeding. Same result 
have been shown in some other studies too [32, 33]. However, one study that followed patients with Rockall score $\geq 6$ for 3.5 year found that these patients were at risk of long term recurrent peptic ulcer bleeding [34]; therefore, in our study increasing length of follow up may lead to a different result.

Table 6

Patient characteristics in missing value group

\begin{tabular}{|c|c|}
\hline Characteristic & Value \\
\hline Age, year & $60.47 \pm 18.77$ \\
\hline \multicolumn{2}{|l|}{ Sex } \\
\hline Male & $148[59.9]$ \\
\hline Female & $99[40.1]$ \\
\hline \multicolumn{2}{|l|}{ Comorbidity } \\
\hline Disseminated malignancy & $10[4]$ \\
\hline Malignancy of upper GI & $28[11.3]$ \\
\hline Liver failure & $10[4]$ \\
\hline Renal failure & $10[4]$ \\
\hline Heart failure & $13[5.3]$ \\
\hline Other cardiac disease [e.g. Ischemic heart disease] & $33[13.4]$ \\
\hline Other renal disease & $8[3.2]$ \\
\hline Other & $17[6.9]$ \\
\hline \multicolumn{2}{|l|}{ Laboratory variables } \\
\hline 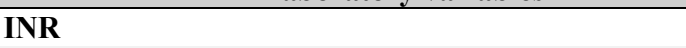 & $1.17 \pm 0.52$ \\
\hline Albumin & $3.54 \pm 0.56$ \\
\hline BUN & $34.80 \pm 28.0$ \\
\hline Hemoglobin & $9.19 \pm 3.01$ \\
\hline \multicolumn{2}{|l|}{$\begin{array}{r}\text { Etiology of upper GI bleeding } \\
\end{array}$} \\
\hline Erosive disease & $88[36.8]$ \\
\hline Peptic ulcer & $84[35.1]$ \\
\hline Malignancy of upper GI & $24[10]$ \\
\hline Varices & $9[3.8]$ \\
\hline No lesion identified & $8[3.3]$ \\
\hline other & $24[10]$ \\
\hline
\end{tabular}

Data are presented as mean \pm SD or number [\%].

Aiming to find a preferred risk score for general assessment of patients, we defined composite of adverse outcomes as a new endpoint and evaluated the ability of risk scores in predicting this endpoint. Although, all scores had statistically significance accuracy, their performance was not remarkable. Nevertheless, it is worth noting that by adding albumin to GBS, this score's accuracy in predicting composite of adverse outcomes increased from 0.57 to 0.66 and made it more accurate than other scores.

Hypoalbuminemia is common in patients with non variceal UGIB and some studies have introduced it as an independent factor in predicting inpatient mortality and other adverse outcome. This can be due to higher frequency of hypoalbuminemia in patients with malnutrition and some chronic diseases (e.g. renal disease, cardiovascular disease and diabetes) $[12,21,22,35]$. In our study, the mean of serum albumin was lower in non-survival group comparing to survival group and the mean of total population was 3.54 which was lower than normal population. Interestingly, in our study albumin could independently predict mortality with AUROC of $0.74(\mathrm{p}<0001)$. This predicting accuracy was even higher than other original scores and may lead to this conclusion that albumin is the simple and easy tool for triaging patients in emergency wards. However, this finding needs further studies to compare albumin with other risk scores in predicting mortality. We assume that the better performance of AIMS65 in predicting mortality may also be related to albumin, since neither GBS nor FRS includes albumin as a risk factor. Supporting this theory, we added albumin to GBS and showed that the combined model had the highest accuracy among risk scores in predicting inpatient mortality.

Of 810 patients in our study, 247 patients didn't have sufficient data and the most missing data was Albumin. The same finding was reported by Stanley, J. et al., in the largest prospective comparison of the risk scores [27]. This finding raises this concern that the importance of measuring serum albumin in UGIB is underrated in our hospital. 
Conspicuously, classifying patients in to high risk and low risk group is crucial and yet a challenging step for management of UGIB. One of the barriers is finding an optimal cut off point for risk scores [24]. In our study we used the cutoff point that maximized the sum of the sensitivity and the specificity in mortality to stratify patients in to high risk and low risk group. This cut off was 2 for AIMS65, 8 for GBS and 6 for FRS and we found that all adverse outcomes excluding rebleeding were higher in high risk group $(\mathrm{p}<0.05)$.

International consensus suggests that low risk groups can be managed as outpatient [13]. This concept is very attractive as the majority of costs associated with UGIB are due to inpatient hospital bed days and outpatient management of these patients could potentially lead to significant savings in cost and resources $[2,14,36]$. In a prospective study, Girardin, M. et al., showed that discharging low risk patients decreased management cost significantly versus inpatient management [36].

A systematic review conducted by Ramaekers, $\mathrm{R}$. et al. comparing different scoring systems suggested that GBS with a cutoff point of 0 was superior over other cut off points and risk scores for identifying low risk patient [37]. This cut off was increased to $\leq 1$ in the prospective study conducted by Stanley, J. et al. and except one, none of the patients required intervention nor transfusion [27]. This cut off has also been extended safely to $\leq 2$ in some studies $[2,24,25]$. Increasing the cutoff point acts as two edged sword. Higher cut off can identify more low risk patient leading to even more reduction in cost; while, in the meantime, the risk of adverse outcome increases [2, 14, 24, 38]. In our study no patients died within GBS $\leq 2$ and $3.39 \%$ had adverse outcome of 30-day rebleeding and need for endoscopic therapy while in AIMS65 $=0,14.28 \%$ had adverse outcome and $1.29 \%$ (3 patients) had mortality. Comparing negative predictive value of these two risk scores, GBS was better than AIMS65 for safe discharge (96.61 vs 85.71).

Although patients with GBS $=0$ are considered safe for discharge, care must be taken with patients with some comorbidities and history of peptic ulcer since these factors have been shown to act as an independent risk factor for mortality and endoscopic intervention [3, 8]. Since hypoalbuminemia is associated with several comorbidities, we assume using a combined model of Albumin-GBS may help clinician in their judgement for safer discharge.

In order to increase the ability of AIMS65 in identifying high risk groups, we changed the threshold for albumin from $<3$ to $<3.5$. Consequently, the negative predictive value for predicting adverse outcome in score $=0$ increased from $85.71 \%$ to $90.22 \%$. Supporting this modification, we found that $41.17 \%$ of non-survival group had Albumin ranging between 3 to 3.5 . of them, $85.71 \%$ were considered as low risk group. As mentioned earlier, the resultant predictive accuracy in mortality was also slightly higher than the original version of AIMS65 (0.72 vs 0.67). Although different levels have been proposed for Albumin as a prognostic factor [21-23], we found that increasing the threshold may increase the likelihood of identifying high risk patients and safer discharge of low risk groups. In addition to lower cost resulting from discharging low risk patients, identifying high risk patients and performing urgent endoscopy ( $<8$ hours) may also be related to reduced hospitalization periods and potentially lower costs [39].

Variceal UGIB (VUGIB) is a severe complication of liver cirrhosis and results in more hospital complications and units of blood transfusion compared to non variceal UGIB [5]. $2.3 \%$ of patients had VUGIB in our study. Several studies have compared the effectiveness of risk scores exclusively in VUGIB and confirmed that AIMS65 predicts mortality more accurate than other risk scores including MELD and CHILD which were designed specifically for patients with liver failure $[40,41]$. This can be explained by two factors of INR and albumin in AIMS65 as they are independent factors for liver state.

Despite the fact that use of risk scores in management of UGIB is recommended in several studies and guidelines [2, 13, 14], its role in actual clinical decisions and hospital guidelines is still unclear [17]. Although, some studies proved that risk scores are a stronger predictor than clinical decision, others believe the opposite [2, 18, 19]. This controversy may originate from variations in hospital characteristic; however, in our hospital, as patients are initially assessed by junior doctors, using risk scores seems to be preferred approach.

There are some limitations in our study. First, our study only included patient who underwent upper endoscopy, this can lead to exclusion of unstable patients; therefore, the applicability of scoring systems in identifying high risk group is still questioned in our study. Second, our study was retrospective and some patients were excluded due to lack of required data. Third, our center is a teaching hospital and patients are initially evaluated by junior doctors and this may lead to misdiagnosis of some subjective data (e.g. mental status and syncope). Lastly, our 
study was single center and the results may not be applicable to other medical centers.

\section{CONCLUSION}

We concluded that although neither of risk scores were highly accurate as a prognostic factor in our population, modified AIMS65 and albuminGBS may be optimal choice in evaluating risk of inpatient mortality and general assessment. Further prospective studies comparing albumin with other risk scores and also validating our modified models and their applicability in clinical practice are suggested. In identifying patient for safe discharge, GBS $\leq 2$ seemed to be an advisable choice.

Introducere. Managementul hemoragiei digestive superioare (HDS) este foarte important. Scopul studiului a fost de a evalua performanța a trei scoruri (AIMS65, Glasgow-Blatchford Score (GBS) și Full Rockall Score (FRS)) pentru a prezice efectele negative ale HDS, precum și capacitatea lor de a identifica pacienții cu riscul cel mai mic. Totodată s-a dorit să se afle dacă schimbarea valorii prag pentru albumina din scorul AIMS65 sau adiția albuminei la scorul GBS adangă valoare predictivă.

Materiale şi metode. A fost realizat un studiu retrospectiv în care au fost incluși pacienții cu HDS internați într-o clinică din Iran în perioada 21 martie 201321 martie 2017. Pacienții cu date insuficiente au fost excluși. Au fost calculate scorurile AIMS65, GBS sau FRS. Efectele primare analizate au fost mortalitatea intraspitalicească, rata resângerărilor la 30 de zile, necesitatea transfuziilor, precum și aplicarea terapiei endoscopice. Efectul secundar a fost reprezentat de un efect compozit ce a inclus efectele primare.

Rezultate. Din cei 563 de pacienți, 3\% au decedat in spital, 69,4\% au necesitat transfuzii de sânge, $13,1 \%$ au necesitat terapie endoscopică și $3 \%$ au avut resângerare în decurs de 30 de zile. Cea mai frecventă cauză a HDS a fost boala erozivă. Cea mai bună capacitate predictivă pentru predicția efectului compozit a avut-o scorul albumină-GBS. Pentru predicția mortalității intraspitalicești numai albumina-GBS, scorul AIMS65 modificat și scorul AIMS65 au avut valori acceptabile. Albumina a avut o capacitate predictivă superioară faţă de celelalte scoruri. Niciun scor nu a prezis riscul de resângerare la 30 de zile.

Concluzii. Niciun scor nu a avut capacitate predictivă foarte bună. Totuşi, scorul AIMS65 modificat și scorul albumină-GBS par e să fie o opțiune pentru evaluarea pacienților cu HDS. Scorul GBS $\leq 2$ este o valoare prag acceptată pentru a externa în siguranță pacientul.

Correspondence to: Ali Akbar Samadani, Ph.D., Gastrointestinal and Liver Diseases Research Center, Guilan University of Medical Science, Rasht, Iran

E-mail: a_a_hormoz@yahoo.com

Conflict of interest disclosure: The authors declare that there is no conflict of interest.

Acknowledgments. The authors would like to thank the Student Research Committee, Faculty of Medicine, Guilan University of Medical Sciences, Rasht, Iran for facilitating the performance of the present study, Research ID 96020206.

Author contributions: F.GH and Z.M designed, collected data and wrote the whole manuscript. F.GH accomplished the statistical analysis and data processing. A.SH and AAS managed the process and edited the final version of the manuscript. All authors read and approved the final manuscript. 


\section{REFERENCES}

1. SALTZMAN JR., TABAK YP., HYETT BH., SUN X., TRAVIS AC., JOHANNES RS. A simple risk score accurately predicts in-hospital mortality, length of stay, and cost in acute upper GI bleeding. Gastrointest Endosc. 2011; 74(6):1215-24.

2. WADDELL KM., STANLEY AJ. Risk assessment scores for patients with upper gastrointestinal bleeding and their use in clinical practice. Hosp Pract(1995). 2015; 43(5):290-8.

3. TAKATORI Y., KATO M., SUNATA Y., HIRAI Y., KUBOSAWA Y., ABE K., et al. The role of history of gastro-duodenal ulcer in patients with upper gastrointestinal bleeding. Dig Dis. 2018; 36(3):177-81.

4. KUMAR NL., CLAGGETT BL., COHEN AJ., NAYOR J., SALTZMAN JR. Association between an increase in blood urea nitrogen at 24 hours and worse outcomes in acute nonvariceal upper GI bleeding. Gastrointest Endosc. 2017; 86(6):1022-7.e1.

5. BUNCHORNTAVAKUL C., YODKET Y., SINGHASENA N. Clinical characteristics, treatment outcomes and risk assessment of patients with acute upper gastrointestinal bleeding in Rajavithi Hospital, Thailand. J Med Assoc Thai. 2017; 100 Suppl 1:S104-15.

6. NAHON S., HAGEGE H., LATRIVE JP., ROSA I., NALET B., BOUR B., et al. Epidemiological and prognostic factors involved in upper gastrointestinal bleeding: results of a French prospective multicenter study. Endoscopy. 2012; 44(11):998-1008.

7. JAIRATH V., KAHAN BC., STANWORTH SJ., LOGAN RF., HEARNSHAW SA., TRAVIS SP., et al. Prevalence, management, and outcomes of patients with coagulopathy after acute nonvariceal upper gastrointestinal bleeding in the United Kingdom. Transfusion. 2013; 53(5):1069-76.

8. DANGO S., BEISSBARTH T., WEISS E., SEIF AMIR HOSSEINI A., RADDATZ D., ELLENRIEDER V., et al. Relevance of surgery in patients with non-variceal upper gastrointestinal bleeding. Langenbecks Arch Surg. 2017; 402(3):509-19.

9. LIANG CM., LEE JH., KUO YH., WU KL., CHIU YC., CHOU YP., et al. Intravenous non-high-dose pantoprazole is equally effective as high-dose pantoprazole in preventing rebleeding among low risk patients with a bleeding peptic ulcer after initial endoscopic hemostasis. BMC Gastroenterol. 2012; 12:28.

10. LEE SH., MIN YW., BAE J, LEE H., MIN BH., LEE JH., et al. Lactate parameters predict clinical outcomes in patients with nonvariceal upper gastrointestinal bleeding. J Korean Med Sci. 2017; 32(11):1820-7.

11. EL-KERSH K., CHADDHA U., SINHA RS., SAAD M., GUARDIOLA J., CAVALLAZZI R. Predictive role of admission lactate level in critically ill patients with acute upper gastrointestinal bleeding. J Emerg Med. 2015; 49(3):318-25.

12. MONTAÑO LAJRDGDM. Clinical impact of serum albumin on nonvariceal upper gastrointestinal bleeding. Rev Gastroenterol Mex. 2016; 81(4):181.

13. BARKUN AN., BARDOU M., KUIPERS EJ., SUNG J., HUNT RH., MARTEL M., et al. International consensus recommendations on the management of patients with nonvariceal upper gastrointestinal bleeding. Ann Intern Med. 2010; 152(2):101-13.

14. SUNG JJ., CHIU PC., CHAN FK., LAU JY., GOH KL., HO LH., et al. Asia-Pacific working group consensus on non-variceal upper gastrointestinal bleeding: an update 2018. Gut. 2018; 67(10):1757-68.

15. BLATCHFORD O., MURRAY WR., BLATCHFORD MJTL. A risk score to predict need for treatment for uppergastrointestinal haemorrhage. The Lancet. 2000; 356(9238):1318-21.

16. ROCKALL T., LOGAN R., DEVLIN H., NORTHFIELD TJG. Risk assessment after acute upper gastrointestinal haemorrhage. Gut. 1996; 38(3):316-21.

17. LEIMAN DA., MILLS AM., SHOFER FS., WEBER AT., LEIMAN ER., RIFF BP., et al. Glasgow Blatchford Score of limited benefit for low-risk urban patients: a mixed methods study. Endosc Int Open. 2017; 5(10):E950-e8.

18. DE GROOT N., VAN OIJEN M., KESSELS K., HEMMINK M., WEUSTEN B., TIMMER R., et al. Prediction scores or gastroenterologists' Gut Feeling for triaging patients that present with acute upper gastrointestinal bleeding. United European Gastroenterol J. 2014; 2(3):197-205.

19. FAROOQ FT., LEE MH., DAS A., DIXIT R., WONG RC. Clinical triage decision vs risk scores in predicting the need for endotherapy in upper gastrointestinal bleeding. Am J Emerg Med. 2012; 30(1):129-34.

20. STANLEY A., ASHLEY D., DALTON H., MOWAT C., GAYA D., THOMPSON E., et al. Outpatient management of patients with low-risk upper-gastrointestinal haemorrhage: multicentre validation and prospective evaluation. The Lancet. 2009; 373(9657):42-7.

21. GONZALEZ-GONZALEZ JA., VAZQUEZ-ELIZONDO G., GARCIA-COMPEAN D., GAYTAN-TORRES JO., FLORESRENDON AR., JAQUEZ-QUINTANA JO., et al. Predictors of in-hospital mortality in patients with non-variceal upper gastrointestinal bleeding. Rev Esp Enferm Dig. 2011; 103(4):196-203.

22. GONZÁLEZ-GONZÁLEZ JA., VÁZQUEZ-ELIZONDO G., MONREAL-ROBLES R., GARCÍA-COMPEAN D., BORJASALMAGUER OD., HERNÁNDEZ-VELÁZQUEZ B., et al. Hypoalbuminemia in the outcome of patients with non-variceal upper gastrointestinal bleeding. Rev Gastroenterol Mex. 2016; 81(4):183-9.

23. WENG SC., SHU KH., TARNG DC., TANG YJ., CHENG CH., CHEN CH., et al. In-hospital mortality risk estimation in patients with acute nonvariceal upper gastrointestinal bleeding undergoing hemodialysis: a retrospective cohort study. Ren Fail. 2013; 35(2):243-8.

24. BANISTER T., SPIKING J., AYARU L. Discharge of patients with an acute upper gastrointestinal bleed from the emergency department using an extended Glasgow-Blatchford Score. BMJ open Gastroenterol. 2018; 5(1):e000225.

25. CHATTEN K., PURSSELL H., BANERJEE AK., SOTERIADOU S., ANG Y. Glasgow Blatchford Score and risk stratifications in acute upper gastrointestinal bleed: can we extend this to 2 for urgent outpatient management? Clin Med. 2018; 18(2):118-22.

26. MOKHTARE M., BOZORGI V., AGAH S., NIKKHAH M., FAGHIHI A., BOGHRATIAN A., et al. Comparison of GlasgowBlatchford score and full Rockall score systems to predict clinical outcomes in patients with upper gastrointestinal bleeding. Clin Exp Gastroenterol. 2016; 9:337-43.

27. STANLEY AJ., LAINE L., DALTON HR., NGU JH., SCHULTZ M., ABAZI R., et al. Comparison of risk scoring systems for patients presenting with upper gastrointestinal bleeding: international multicentre prospective study. BMJ. 2017; 356:i6432. 
28. GU L., XU F., YUAN J. Comparison of AIMS65, Glasgow-Blatchford and Rockall scoring approaches in predicting the risk of in-hospital death among emergency hospitalized patients with upper gastrointestinal bleeding: a retrospective observational study in Nanjing, China. BMC Gastroenterol. 2018; 18(1):98.

29. ROBERTSON M., MAJUMDAR A., BOYAPATI R., CHUNG W., WORLAND T., TERBAH R., et al. Risk stratification in acute upper GI bleeding: comparison of the AIMS65 score with the Glasgow-Blatchford and Rockall scoring systems. Gastrointest Endosc. 2016; 83(6):1151-60.

30. KALKAN C., SOYKAN I., KARAKAYA F., TUZUN A., GENCTURK ZB. Comparison of three scoring systems for risk stratification in elderly patients with acute upper gastrointestinal bleeding. Geriatr Gerontol Int. 2017; 17(4):575-83.

31. YANG HM., JEON SW., JUNG JT., LEE DW., HA CY., PARK KS., et al. Comparison of scoring systems for nonvariceal upper gastrointestinal bleeding: a multicenter prospective cohort study. J Gastroenterol Hepatol. 2016; 31(1):119-25.

32. CURDIA GONCALVES T., BARBOSA M., XAVIER S., BOAL CARVALHO P., FIRMINO MACHADO J., MAGALHAES J., et al. Optimizing the risk assessment in upper gastrointestinal bleeding: comparison of 5 Scores predicting 7 outcomes. GE Port J Gastroenterol. 2018; 25(6):299-307.

33. WANG CH., CHEN YW., YOUNG YR., YANG CJ., CHEN IC. A prospective comparison of 3 scoring systems in upper gastrointestinal bleeding. Am J Emerg Med. 2013; 31(5):775-8.

34. YANG EH., CHENG HC., WU CT., CHEN WY., LIN MY., SHEU BS. Peptic ulcer bleeding patients with Rockall scores $>/=6$ are at risk of long-term ulcer rebleeding: A 3.5-year prospective longitudinal study. J Gastroenterol Hepatol. 2018; 33(1):156-63.

35. TUNG CF., CHOW WK., CHANG CS., PENG YC., HU WH. The prevalence and significance of hypoalbuminemia in non-variceal upper gastrointestinal bleeding. Hepatogastroenterology. 2007; 54(76):1153-6.

36. GIRARDIN M., BERTOLINI D., DITISHEIM S., FROSSARD JL., GIOSTRA E., GOOSSENS N., et al. Use of GlasgowBlatchford bleeding score reduces hospital stay duration and costs for patients with low-risk upper GI bleeding. Endosc Int Open. 2014; 2(2):E74-9.

37. RAMAEKERS R., MUKARRAM M., SMITH CA., THIRUGANASAMBANDAMOORTHY V. The predictive value of preendoscopic risk scores to predict adverse outcomes in Emergency Department patients with upper gastrointestinal bleeding: a systematic review. Acad Emerg Med. 2016; 23(11):1218-27.

38. LAURSEN SB., DALTON HR., MURRAY IA., MICHELL N., JOHNSTON MR., SCHULTZ M., et al. Performance of new thresholds of the Glasgow Blatchford score in managing patients with upper gastrointestinal bleeding. Clin Gastroenterol Hepatol. 2015; 13(1):115-21.e2.

39. PARK SW., SONG YW., TAK DH., AHN BM., KANG SH., MOON HS., et al. The AIMS65 Score is a useful predictor of mortality in patients with nonvariceal upper gastrointestinal bleeding: urgent endoscopy in patients with high AIMS65 Scores. Clin Endosc. 2015; 48(6):522-7.

40. MOHAMMAD AN., MORSY KH., ALI MA. Variceal bleeding in cirrhotic patients: What is the best prognostic score? Turk J Gastroenterol. 2016; 27(5):464-9.

41. MOTOLA-KUBA M., ESCOBEDO-ARZATE A., TELLEZ-AVILA F., ALTAMIRANO J., AGUILAR-OLIVOS N., GONZALEZANGULO A., et al. Validation of prognostic scores for clinical outcomes in cirrhotic patients with acute variceal bleeding. Ann Hepatol. 2016; 15(6):895-901.

Received March $21^{\text {st }} 2019$ 